\title{
The Legal Framework and Barriers to Access to Environmental Information in Ethiopia
}

\begin{abstract}
Information plays a vital role, both in terms of its importance for a democratic order and as a prerequisite for public participation. Many countries have made provisions for access to information in their respective constitutions. The FDRE Constitution explicitly provides that everyone has the right to seek and receive information. The Freedom of Mass Media and Access to Information Proclamation -which entered into force in 2008- gives effect to this Constitutional guarantee. Moreover, the number of laws on different environmental issues is on the rise, and the same could be said of the multilateral environmental agreements that Ethiopia has ratified. Many of the laws incorporate the right of the public to access environmental information held by public bodies. Despite the existing legal framework, there are still notable barriers to access to environmental information. By analyzing the relevant laws, the aim of this article is to contribute to the dialogue on the constitutional right of access to information with particular emphasis on the legal framework on, and the barriers to, access to environmental information within the meaning of Principle 10 of the Rio Declaration.
\end{abstract}

Abdulkader Mohammed Yusuf *

\section{Key terms:}

Ethiopia - Rio Declaration - Access to information - Environment - Public bodies $\cdot$ Active/passive access to environmental information · Barriers

DOI http://dx.doi.org/10.4314/mlr.v15i1.5

This article is licensed under a Creative Commons Attribution-

NonCommercial-NoDerivs (CC BY-NC-ND)

Received: 31 March 2021

Accepted: 28 June 2021

\section{Suggested citation:}

Abdulkader Mohammed Yusuf (2021), 'The Legal Framework and Barriers to Access to Environmental Information in Ethiopia:' 15 Mizan Law Review 1: 139-172.

- Abdulkader Mohammed Yusuf (PhD Candidate, Addis Ababa University School of Law). Currently, the Head of Addis Ababa City Administration Bureau of Attorney. Email: abdu.mohammed08@gmail.com ORCID: https://orcid.org/0000-0002-6662-8605 The author would like to thank the anonymous reviewers. 


\section{Introduction}

Access to information is one of the fundamental rights recognized by many international and regional human rights instruments as well as many constitutions. Information in the hands of public bodies is indeed sine qua non for most fundamental human rights and also vital in environmental matters. In this regard, the Rio Declaration is one of the first instruments to highlight the importance of access to environmental information, along with other procedural environmental rights. ${ }^{1}$ Needless to say, information on environmental matters is important for environmental protection endeavors, in addition to its significance in the constitution of a democratic order.

Many environmental laws have been enacted in Ethiopia since the entry into force of the FDRE Constitution in 1995. Although fragmented, and at times overlapping, the laws regulate various issues in different sectors such as the conservation of biodiversity, water, forest and wildlife, agriculture and animal resources, mineral resources, energy resources as well as laws on pollution and the regulation of hazardous activities and substances. The period has also seen the proliferation of institutions, established in accordance with proclamations or regulations, in charge of overseeing various activities that have a bearing on the environment.

Although there are many laws that require information to be available to the public, there are a number of difficulties. One of the difficulties is the absence of what constitutes environmental information. The environment is

\section{Frequently used acronyms:}

EFCCC Environment, Forest and Climate Change Commission

FDRE Federal Democratic Republic of Ethiopia

${ }^{1}$ See the United Nations Conference on Environment and Development A/CONf.151/26 (Vol. I). Environmental rights are composed of substantive rights (fundamental rights such as the right to clean and healthy environment) and procedural rights (tools used to achieve substantial rights namely the right to information, participation and access to justice). See, for example, the definition of environmental rights at:

https://www.unep.org/explore-topics/environmental-rights-and-governance/what-wedo/advancing-environmental-rights/what

See also, Birgit Peters (2017), 'Unpacking the Diversity of Procedural Environmental Rights: The European Convention on Human Rights and the Aarhus Convention' Journal of Environmental Law, 0, 1-27, p. 2. As will be seen later on, Principle 10 of the Rio Declaration is regarded as the first instrument to clearly recognize procedural environmental rights. As such, these rights do not relate to a right to a specific substantive environmental quality or outcome, but to enjoy certain procedural rights pertaining to the environment. Chris Hislon, 'Substantive environmental rights in the EU: doomed to disappoint?' in Bogojevic, S. \& Rayfuse, R. (eds.), 2018, Environmental Rights in Europe and Beyond. Hart Publishing, p. 88. 
The Legal Framework and Barriers to Access to Environmental Information in Ethiopia 141

defined under the Environmental Protection Organs Proclamation No. 295/2002 and the Environmental Pollution Control Proclamation No. $300 / 2002$. Drawing inspiration from these two laws, environmental information in this article is understood as any information relating to land, water, atmosphere, weather and climate, living things and others. ${ }^{2}$

Over thirty environmental laws on biodiversity, water, land, pollution control and hazardous activities and substances are analyzed in relation to the issue. For reasons of simplicity, the provisions are categorized as active and passive access to information. Moreover, instead of discussing each proclamation/regulation under separate sections, the laws are discussed in respect of their nature i.e. active or passive and the respective institutions obliged to make the information available. As Ethiopia has yet to enact an access to information law or a framework environmental law, the article relies on the access to information provisions of the FDRE Constitution as well as the Freedom of the Mass Media and Information Proclamation.

This article analyzes the legal framework on environmental information and its barriers. As such, it does not go into the practice of access to information in general and access to environmental information in particular. Hence, the practice of the various institutions entrusted with the responsibility of environmental protection and providing the public with environmental information is beyond the scope of this article. The article only covers environmental information held by public bodies.

Apart from this short introduction, the article is organized in four sections. The next section introduces the concept of access to environmental information. Section 3 discusses access to environmental information in Ethiopia. This is done first by discussing the access to information provisions of the FDRE Constitution and the Access to Information Law. The discussion on the legal framework on access to environmental information in Ethiopia is arranged by way of active and passive access to environmental information. Section 4 briefly discusses the remedies available for a person aggrieved by the response to his application for access. The fifth section deals with some of the major barriers to access to environmental information in Ethiopia, followed by concluding remarks.

\footnotetext{
${ }^{2}$ See the Environmental Protection Organs Proclamation No. 295/2002, Article 2 (3) and Environmental Pollution Control Proclamation No. 300/2002, Article 2 (6). The Industrial Chemical Registration and Administration Proclamation No 1075/2018 is a recent example of a law that has resorted to the definition of environment provided under the above 2002 laws.
} 


\section{Access to Environmental Information}

\subsection{Access to information as a fundamental human right}

Access to information is a fundamental right. It is also a prerequisite to many other rights such as public participation in decision making. This is because the public must have information to effectively participate in decision making. Without information, people have no power to make choices about their government and they will not be able to meaningfully participate in the decision-making process, to hold their governments accountable, to thwart corruption, to reduce poverty, or, ultimately, to live in a genuine democracy. ${ }^{3}$ Due to the interdependence of rights, and in order to be able to exercise rights people must be given access to information. ${ }^{4}$

There seems to be no argument with regard to the fundamental nature of the right of access to information. The right is guaranteed in many international instruments. The Universal Declaration on Human Rights recognizes the right to seek, receive and impart information and ideas through any media regardless of frontiers. ${ }^{5}$ Moreover, regional human rights instruments such as the European and the American Conventions as well as the African Charter contain provisions which guarantee the right to receive and impart information. ${ }^{6}$

One possible interpretation of the provisions in these human rights instruments regarding the right to receive information is that a government may not block someone from receiving information, but that there is no specific duty on the part of public bodies to be a provider of information. ${ }^{7}$ The ambiguity on who has the duty to give information is no longer an issue. For instance, it is understood that Article 19 of the International Covenant on Civil and Political Rights (ICCPR) requires governments to "respect and ensure respect" for the right to access information.

${ }^{3}$ Article 19 (2007), Access to Information: An Instrumental Right for Empowerment p. 9. https://www.article19.org/data/files/pdfs/publications/ati-empowerment-right.pdf.

${ }^{4}$ Jagwanth, Saras (2002), 'The Right to Information as a Leverage Right' in The Right to Know, The Right to Live: Access to Information and Socio-Economic Justice, Calland, Richard and Allison Tilley, ed. Open Democracy Advice Centre, p. 7 in Article 19, supra note 3.

${ }^{5}$ UDHR Article 19. Article 19 (2) of the International Covenant on Civil and Political Rights is also formulated in similar terms as Article 19 of the UDHR.

${ }^{6}$ See the European Convention for the Protection of Human Rights and Fundamental Freedoms, Article 10; the American Convention on Human Rights, Article 13; and the African Charter on Human and Peoples' Rights, Article 9.

${ }^{7}$ Svitlana Kravchenko (2010), 'Is Access to Environmental Information a Fundamental Human Right?' Oregon Review of International Law, Vol. 11, p. 230. 
The Legal Framework and Barriers to Access to Environmental Information in Ethiopia 143

As a negative obligation, the government must respect the right by not violating it directly through legislation, policies, judicial decisions or actions. ${ }^{8}$ As a positive obligation, the government is required to take action to protect the right by preventing others from violating it or to fulfill the right by adopting legislative and other measures. ${ }^{9}$ This has been affirmed by the African Commission on Human and Peoples Right's Declaration of Principles on Freedom of Expression in Africa which states that "public bodies hold information not for themselves but as custodians of the public good and everyone has a right to access this information, subject only to clearly defined rules established by law". ${ }^{10}$

This shows that the understanding of the right has developed to encompass a concrete and immediate obligation on the government to provide information, as well as to refrain from any interference. ${ }^{11}$ Such a broad understanding of the right is illustrated by the growth in government openness in recent years and the increasing number of countries enacting access to information laws. ${ }^{12}$

\subsection{A brief account of the development of access to environmental information}

Environmental information comprises information pertaining to air, water, land, living things as well as laws, policies and decisions that affect the environment. It includes information on actions and courses of conduct that may affect the environment and facilitate effective public participation in environmental decision-making. ${ }^{13}$ "The information shall be timely, clear,

${ }^{8}$ Asbjorn Eide, (1989), 'Realization of Social and Economic Rights and the Minimum Threshold Approach', Human Rights Law Journal, 35, in Article 19, supra note 3, at 15.

${ }^{9}$ Article 19, supra note 3, at15.

${ }^{10}$ Declaration of Principles on Freedom of Expression in Africa, Afr. Comm'n on Hum. and Peoples' Rights, 32 ${ }^{\text {nd }}$ Sess., (Oct. 23, 2002),

http://www.achpr.org/english/declarations/declaration_freedom_exp_en.html in Kravchenko, supra note 7, at 231. The Inter-American Court of Human Rights also held the same view in Claude Reyes $v$. Chile where it stated "by expressly stipulating the right to 'seek' and 'receive' information, Article 13 of the American Convention on Human Rights protects the right of all individuals to request access to State-held information, with the exceptions permitted by the restrictions established in the Convention."

${ }^{11}$ Article 19, supra note 3, at 6.

${ }^{12}$ Ibid.

${ }^{13}$ Tim Hayward (2005), Constitutional Environmental Rights, OUP, p. 30. 
understandable and available without undue financial burden to the applicant". ${ }^{14}$

Principle 10 of the Rio Declaration is regarded as a pioneer in providing environmental rights in clear terms. ${ }^{15}$ It provides that "[e]nvironmental issues are best handled with the participation of all concerned citizens at the relevant level." At the national level, each individual shall have appropriate access to information concerning the environment that is held by public authorities, including information on hazardous materials and activities in their communities." 16

The influence of Principle 10 of the Rio Declaration can easily be felt when one looks into the development of both national environmental legislation and multilateral environmental agreements that came into the picture since. Prime among these is the Convention on Access to information, Public Participation in Decision Making and Access to Justice in Environmental Matters, commonly known as the Aarhus Convention, which was adopted in 1998 and entered into force in 2001. The Aarhus Convention is regarded as a point of departure in any discussion of the three fundamental rights, sometimes referred to as the three pillars of environmental democracy: access to information, public participation and access to justice in environmental matters. ${ }^{17}$ Although originally adopted having certain European countries in

${ }^{14}$ Ibid.

15 The Stockholm Declaration under Principle 19 deals with the dissemination of information of an educational nature on the need to project and improve the environment by the mass media. However, the Principle is not framed in terms of a duty on the part of the State and a right of the public to require information pertaining to the environment. As will be seen later on, the discussion in this article is framed in terms of the duty on the part of the public bodies and the right of the public.

16 Along with access to information in environmental matters, Principle 10 of the Rio Declaration also deals with public participation in environmental decision making and access to justice.

17 The 'access rights' are very important in promoting transparent, inclusive and accountable environmental governance. Access to information empowers citizens and motivates them to participate in decision and policy making processes in an informed manner. Public participation is increasingly being seen as a vital part of addressing environmental problems. Access to justice provides the foundation for the other 'access rights' as it facilitates the public's ability to enforce their right to participate, to be informed, and to hold regulators and polluters accountable for environmental harm. Benson Ochieng (2015), 'Implementing Principle 10 and the Bali Guidelines in Africa', UNEP pp. i and 2. See also Belén O Giupponi (2019), 'Fostering environmental democracy in Latin America and the Caribbean: An analysis of the Regional Agreement on Environmental Access Rights' RECIEL; 00:1-16.

https://doi.org/10.1111/reel.12274. 
The Legal Framework and Barriers to Access to Environmental Information in Ethiopia 145

mind, the Convention is worthy of a discussion as it is open for non-European countries as well. ${ }^{18}$

Despite all the politics attached to it, ${ }^{19}$ the Convention is the first international instrument that unequivocally develops the right of the public to access information, to participate in decision making and to access justice. ${ }^{20}$ By doing so, the Convention in essence injected life into Principle 10 of the Rio Declaration by providing for applicable mechanisms whereby the three pillars of environmental democracy would be implemented in the States Parties. "It represents probably the most important step yet taken towards environmental rights protection: it recognizes rights to information, to participation in decision making and to access to justice in environmental matters which it expressly affirms are aimed at securing the right to healthy environment". ${ }^{21}$ Although the Convention is only binding with regard to these procedural rights, its preamble expressly indicates the rationale of the procedural rights by stating that "every person has a right to live in an environment adequate to his or her health and well-being". ${ }^{22}$

The Convention recognizes two ways of providing environmental information: active and passive access to information. Active access to information, under Art. 5 of the Convention, relates to information whereby public authorities collect and disseminate environmental information. ${ }^{23} \mathrm{On}$

${ }^{18}$ Article 19(2) of the Aarhus Convention provides that any State that is a member of the United Nations may accede to the Convention upon approval by the Meeting of the Parties. Accordingly, the Convention was signed by thirty-five countries from Europe and parts of Central Asia, the United States, Canada and Israel, although the North American countries opted out of the Process. See Hayward, supra note 13, at 57 and 144.

${ }^{19}$ It is claimed that secrecy was a fundamental characteristic of the former Eastern Bloc countries, where the political system in place during the former Soviet Union did not recognize the right to access information held by public bodies, which considered information they possessed as their own domain. By endorsing the three procedural environmental rights of information, participation and justice, the Convention reaffirmed those rights as prerequisites for establishing and maintaining effective democratic order. See Tatiana Zaharachenko and Gretta Goldenman (2004), 'Accountability in Governance: The Challenge of Implementing the Aarhus Convention in Eastern Europe and Central Asia', Kluwer 229-251, p. 234.

${ }^{20}$ Elli Louka (2006), International Environmental Law: Fairness, Effectiveness, and World Order, CUP, p. 129.

${ }^{21}$ Hayward, supra note, 13, at 57.

22 Id. 57-58.

23 Stephen Stec and Susan Casey-Lefkowits (2000), 'The Aarhus Convention: An Implementation Guide; United Nations New York and Geneva; p. 66 in Marija Kostic 
the other hand, Article 4 of the Convention sets out the frameworks and regulates the procedures for release of environmental information on the demand of the public/individuals, and calls upon States Parties to implement it in their national legislation. ${ }^{24}$

Other than national laws and multilateral environmental agreements, access to environmental information has also been reiterated at the Rio+20, where it is underscored under paragraph 43 that access to information is essential to the promotion of sustainable development. ${ }^{25}$ Paragraph 43, indeed, reaffirms the importance of access to information and participation of all for the realization of sustainable development.

\subsection{Theoretical Basis for Access to Environmental Information}

\subsubsection{Access to environmental information as a vital component of democracy}

It is claimed that "the most significant developments in actual environmental rights provision to date have centered on procedural rights with respect to matters of specifically environmental substance". ${ }^{26}$ As Hayward notes, "These rights - of access to environmental information, participation, and access to justice in environmental matters- have received widespread support from environmental campaigners, have been recognized as workable rights by legal commentators, and have been increasingly endorsed by governments." 27 Among these, access to environmental information is a prerequisite for both

(2006), 'The Right of Access to Environmental Information in the Sense of the Aarhus Convention: European Streams and Legal Framework in Serbia and Montenegro' PhD dissertation, European University Viadrina, p. 63.

${ }^{24}$ Id. 100.

${ }^{25}$ See 'The Future We Want' (Outcome document of the United Nations Conference on Sustainable Development, Rio de Janeiro, 20-22 June 2012). The relevant part of paragraph 43 reads:

We underscore that broad public participation and access to information and judicial and administrative proceedings are essential to the promotion of sustainable development. Sustainable development requires the meaningful involvement and active participation of regional, national and subnational legislatures and judiciaries, and all major groups: women, children and youth, indigenous peoples, nongovernmental organizations, local authorities, workers and trade unions, business and industry, the scientific and technological community, and farmers, as well as other stakeholders, including local communities, volunteer groups and foundations, migrants and families, as well as older persons and persons with disabilities.

${ }^{26}$ Hayward, supra note 13, at 143.

${ }^{27}$ Ibid. 
The Legal Framework and Barriers to Access to Environmental Information in Ethiopia 147

the exercise of the other rights as well as towards the establishment of a democratic order.

As noted above, a very good example of promoting access to environmental information as a prerequisite for a democratic order is the Aarhus Convention which, by promoting the three procedural rights to information and participation and access to justice, aims at bringing some states to some level of democracy. Indeed, access to environmental information promotes transparency of any government on the one hand and brings the public on board for effective participation on the other. Access to information allows the public to stay informed of governmental decisions that can impact the environment and individual lives. ${ }^{28}$ "If the aim of such rights is to open up new areas of public debate, to bring an increased range of decisions into the sphere of influence of citizens, and to provide a counterbalance to the substantive values promoted by existing rights, then they have a prima facie claim to be considered democratic rights". ${ }^{29}$

In line with this, many constitutions promulgated in the past few decades have incorporated the right of access to information, which certainly applies to any information including environmental information. This makes sense given the fact that many constitutions claim to establish a democratic system of government, in their own rights, where certain principles such as transparency and participation hold essential places. Thus, it comes as no surprise that, by 2006 , over 80 countries have adopted a constitutional provision guaranteeing the right; most newly written constitutions include a right of access; a number of countries with older constitutions like Finland and Norway have recently amended their constitutions to specifically include the right of access to information. ${ }^{30}$

Although the first access to information law was enacted in Sweden in 1776 , countries appeared reluctant to enact access to information laws. However, the number of countries which have enacted enabling legislation implementing the constitutional right of access to information shows a steady growth in the past decades. Out of the 115 countries which have enacted access to information laws, 104 have done so since $1990 .{ }^{31}$ In some countries,

${ }^{28}$ Kravchenko, supra note 7, at 228.

${ }^{29}$ Hayward, supra note 13, at144.

${ }^{30}$ David Banisar (2006), 'Freedom of Information around the World 2006: A Global Survey of Access to Government Information Laws', Privacy Int'l, p. 17 in Kravchenko supra note 7 , at 231.

${ }^{31}$ See the list of countries which have access to information laws at: 
access to information laws have even been accorded a rank as high as their constitutions. $^{32}$ This shows the important place that access to information has attained through the years. It goes without saying that environmental information is so vital that any reference to access to information includes access to environmental information.

\subsubsection{Access to environmental information for environmental protection}

The case for access to environmental information for environmental protection is borne out of two closely related concepts: the public's right to live in a clean and healthy environment and the duty to protect the environment. It is maintained that the duty to protect the environment is not solely borne by the government, but one shared between the government, the public, the private sector, civil societies and other stakeholders. In order to enjoy the right to clean environment and contribute in the protection of the environment, timely and accurate information is a prerequisite.

Hence, broad access to information is the foundation for sound environmental governance, because it enables the public to learn about environmental threats and to decide how best to respond. ${ }^{33}$ This principle ensures that citizens have a right to obtain information about the state of the environment and human health; factors affecting or potentially affecting the environment (such as sources of pollution); proposed projects that could affect the environment; and laws, policies, and international agreements potentially affecting the environment. ${ }^{34}$ Only then can one talk about the right of public participation in environmental decision making, because an uninformed public cannot effectively participate in environmental protection endeavors.

The public needs information as an important component of the right to live in a clean and healthy environment. Information is also vital for the public, being a vital partner, to discharge its duties of protecting the

http://www.freedominfo.org/?p=18223 accessed 12 February 2019.

${ }^{32}$ In Sweden, the Freedom of the Press Act is one of the four fundamental laws that make up the Swedish Constitution. Any changes to it require a stringent procedure over two Parliaments. Some countries have given the information laws a higher legal status. In Canada, the courts have recognized the Access to Information Act as "quasi Constitutional." In New Zealand, the Court of Appeals decided in 1988 that "the permeating importance of the [Official Information] Act is such that it is entitled to be ranked as a constitutional measure." See Kravchenko supra note 7, at 18.

${ }^{33}$ Carl Bruch, 'Regional Opportunities for Improving Environmental Governance through Access to Information, Public Participation and Access to Justice', ( $8^{\text {th }}$ Session of the African Ministerial Conference on Environment (AMCEN) Abuja, Nigeria, 3-6 April 2000), p. 3.

${ }^{34}$ Ibid. 
The Legal Framework and Barriers to Access to Environmental Information in Ethiopia 149

environment. For example, the idea that the public should have the right to influence decisions about the environment constitutes a basic requirement for the achievement of sustainable development. ${ }^{35}$ Good environmental governance ensures public participation in the preparation and implementation of environmental policies, legal frameworks, plans and projects. ${ }^{36}$ In other words, "[a]n informed public can contribute meaningfully to decision-making on environmental issues and act as a watchdog supplementing governmental environmental management and supervision efforts" ${ }^{37}$ This is why "participatory rights are regarded as essential ingredients for securing substantive constitutional rights, in the absence of which constitutional rights can wither on the vine". ${ }^{38}$

\section{Access to Environmental Information in Ethiopia}

In Ethiopia, the term environment is defined as:

the totality of all materials whether in their natural state or modified or changed by human, their external spaces and the interactions which affect their quality or quantity and the welfare of human or other living beings, including but not restricted to, land, atmosphere, weather and climate, water, living things, sound, odor, taste, social factors, and aesthetics. ${ }^{39}$

One may, therefore, take inspiration from this expansive definition of environment. Naturally, environmental information may be in respect of any one of the above mentioned areas, or even more. The following sub-sections discuss the legal framework on access to environmental information in Ethiopia.

${ }^{35}$ Christoph Schwarte, Access to Environmental Information in Uganda Forestry and Oil Production, Foundation for International Environmental Law and Development (FIELD) and the International Institute for Environment and Development (IIED) p. 6 , available at

$<$ http://www.accessinitiative.org/sites/default/files/field_access_uganda.pdf $>$ accessed 14 July 2018.

${ }^{36}$ Ibid.

${ }^{37}$ Hayward, supra note 13 , at 178.

38 James May (2013), 'Constitutional Directions in Procedural Environmental Rights' Journal of Environmental Law and Litigation, Vol. 28, Research Paper No. 14-05, available at $<$ SSRN: https://ssrn.com/abstract=2370132> accessed 21 July 2017.

${ }^{39}$ Article 2(3) of the Environmental Protection Organs Establishment Proclamation No. 295/2002, $9^{\text {th }}$ Year No. 7 and 295/2002 and the Article 2(6) of the Environmental Pollution Control Proclamation 300/2002 $9^{\text {th }}$ Year No. 12. 


\subsection{Access to environmental information under the FDRE Constitution and the Access to Information Law}

The FDRE Constitution, which entered into force in 1995, is "the supreme law of the land and any law, customary practice or a decision of an organ of state or a public official which contravenes the Constitution is of no effect". ${ }^{40}$ It is also stipulated that "[a]11 citizens, organs of state, political organizations, other associations as well as their officials have the duty to ensure observance of the Constitution and obey it". 41

Over a third of the Constitution is dedicated to fundamental human rights. All the three organs of the government both at the Federal and State level have the obligation and duty to respect and enforce the fundamental rights and

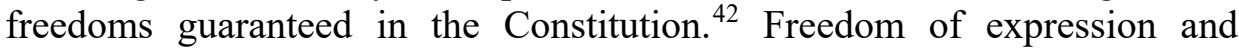
information are some of the fundamental human rights guaranteed under the Constitution. It states that "everyone has the right to freedom of expression without any interference, including freedom to seek, receive and impart information and ideas of all kinds, regardless of frontiers, either orally, in writing or in print, in the form of art, or through any media of his choice". ${ }^{43}$ Freedom of the press to access information of public interest is also guaranteed. ${ }^{44}$ In the interest of the free flow of information, ideas and opinions which are deemed essential to the functioning of a democratic order, the press, as an institution, further enjoys legal protection to ensure its operational independence. ${ }^{45}$

Although the Constitution provides for access to information in general, the argument throughout is that it includes access to environmental information ${ }^{46}$ when one takes into account the spirit of the Constitution. First, it is argued that the Constitution's guarantee of access to information coupled with its emphasis on environmental protection implies that the Constitution aims towards extending its democratic principles to environmental

${ }^{40}$ Constitution of the Federal Democratic Republic of Ethiopia Proclamation No. 1/1995, Year 1 No. 1 (FDRE Constitution), Article 9 (1).

${ }^{41}$ Id. Article 9 (2).

${ }^{42} I d$. Article 13 (1).

${ }^{43} I d$. Article 29 (2).

${ }^{44} I d$. Article 29 (3).

${ }^{45}$ Id. Article 29 (4).

${ }^{46}$ See Desalegn Amsalu (2018), 'Environmental Rights in Ethiopia: Shifting from Theory to Practical Realization', Journal of Sustainable Development Law and Policy, Vol. 9:2, pp. 48-66, 52. 
The Legal Framework and Barriers to Access to Environmental Information in Ethiopia 151

regulation. ${ }^{47}$ Second, the Constitution places special emphasis on the right of the people to live in a clean and healthy environment. ${ }^{48}$ Third, the Constitution states that everyone has the duty to protect the environment. ${ }^{49}$ Finally, the Constitution provides for public participation in the planning and implementation of environmental policies and projects. ${ }^{50}$ In order for these to materialize, access to quality and timely environmental information is a necessity. ${ }^{51}$

To give effect to the Constitutional provisions of access to information and related matters, the Government enacted the Freedom of the Mass Media and Access to Information Proclamation (hereinafter "Access to Information Law") in 2008. Even though the Media Proclamation No. 1238/2021 is enacted in 2021, Article 91(1) of the Proclamation has only repealed the "[p]rovisions concerning mass media on Mass Media and Access to Information Proclamation No. 590/2008" and it does not embody provisions on access to information. Proclamation No. 590/2008 reaffirms the right to seek, obtain and communicate any information in the hands of public bodies, except as expressly provided therein. ${ }^{52}$ One of the many things that inspires optimism in the Access to Information Law is the expansive definition of

47 Abadir M Ibrahim (2009), 'A Human Rights Approach to Environmental Protection: The Case of Ethiopia,' Contemporary Legal Institutions, Vol. 1, Issue 1, 62-74, p. 72.

${ }^{48}$ Id. Article 44 (1).

${ }^{49}$ Although Article 92 (4) of the Constitution uses the word 'citizens', the term should be understood to mean everyone be it non-citizens, NGOs, international organizations etc. The right to a clean and healthy environment and the duty to protect the environment is reiterated in para. 7 of the Preamble to the Aarhus Convention, which states that "every person has the right to live in an environment adequate to his or her health and well-being, and the duty, both individually and in association with others, to protect and improve the environment for the benefit of present and future generations".

${ }^{50}$ See the FDRE Constitution, Article 92 (3).

${ }^{51}$ The relationship between the right to live in a healthy environment and the duty of all to protect the environment is best explained in the Preamble to the Aarhus Convention. Paragraph 7 recognizes every person's "right to live in an environment adequate to his health and well-being, and the duty, both individually and in association with others, to protect and improve the environment for the benefit of present and future generations". The public must, accordingly, have access to information and actively participate in order to assert the right to live in a healthy environment and observe its duty of protecting the environment.

${ }^{52}$ Freedom of the Mass Media and Access to Information Proclamation No. 590/2008 $14^{\text {th }}$ Year No. 64 (Access to Information Law), Article 12(1). 
'information', which is defined as any material recorded in any form by public bodies. $^{53}$

The Law recognizes the right of the media to collect and disseminate information, including those of a critical nature ${ }^{54}$ It also acknowledges "the fundamental importance, in a democracy, of the transparent conduct of government affairs and, in particular, the right of individuals to access information held by public bodies". ${ }^{55}$ It further highlights the importance of promoting the values of transparency and accountability in the conduct of public affairs and of imposing a legal obligation on public officials to facilitate access to information so that matters of public interest may be disclosed and discussed publicly. ${ }^{56}$

Active and passive access to information is envisaged under the Law. Under the title 'Duty to Publish', Article 13 deals with active access to information, whereby a public body is required to publish information on certain pertinent issues regarding the institution concerned. Public bodies are also required to update, at least once a year, such information whenever essential changes take place and make the same available. ${ }^{57}$

Passive access to information is also guaranteed under the Law whereby a person who desires to obtain information presents his request clearly identifying the information he seeks, without having to provide reasons for the request. ${ }^{58}$ The Law requires the public relations officer to assist requesters with illiteracy or physical incapacity. ${ }^{59}$ Upon receipt of the request, the public relations officer either grants the information requested or in the event he rejects the request, provides a written response stating the reasons on any of the grounds within thirty working days. ${ }^{60}$ The public relations officer to whom a request for access is made may extend this thirty working days period for a further thirty days if one of the conditions of Article 14 (8) is satisfied. Subject to Article 14 (3), in the case of a request for information deemed urgent, the

${ }^{53}$ Id. Article 2 (6). Under Article 2 (5), a public body is defined as "anybody established under the FDRE Constitution or state constitution or any other law which forms part of any level or branch of the federal or regional state or owned, controlled or directly or indirectly substantially financed by funds provided by the federal or regional governments or accountable to the federal or regional states".

${ }^{54} I d$. Preamble para. 7.

${ }^{55} \mathrm{Id}$. para 8.

${ }^{56}$ Id. para. 9.

${ }^{57} \mathrm{Id}$. Article 13 (2).

${ }^{58} I d$. Article 14 (1) and (2).

${ }^{59}$ Ibid.

${ }^{60}$ Id. Article 14 (3). 
The Legal Framework and Barriers to Access to Environmental Information in Ethiopia 153

public body that received the request provides the information within a period of ten working days. ${ }^{61}$

\subsection{Active access to environmental information}

Most of the environmental laws in Ethiopia are designed by way of active access to information. This ensures that timely and valuable information is available free of charge. ${ }^{62}$ As with the definition of environment, the governmental institutions entrusted with the responsibility of the protection of the environment in Ethiopia are so diverse. Moreover, under the Aarhus Convention, the requirement is not only to provide information but also to organize it so that it can be effectively accessed; and this is regarded as the innovative element of the Convention. ${ }^{63}$ The Convention is considered as the most important Convention on access to environmental information to date.

Many provisions in environmental laws in Ethiopia are framed in such a way that the public bodies are required to collect, organize and disseminate information. This is in line with the "innovative" element of the Aarhus Convention. As stated above, most of the laws which make provisions for environmental information provide for the institutions responsible for making the information available for the public, i.e. active access to environmental information. $^{64}$

${ }^{61} I d$. Article 14 (9).

62 As will be seen later on, one important problem relating to active access to environmental information is that the remedies under the Access to Information Law are designed in such a way that a person aggrieved by the decision of public bodies may bring a case against them. The Access to Information Law is not, therefore, formulated to entertain complaints on active access to environmental information.

${ }^{63}$ Louka, supra note 20, at 131.

${ }^{64}$ There are a few exceptions to this whereby the law is not clear on how information is made available and the public body required to make information available. One example is the definition of two terms in the Rural Land Administration Proclamation No. 456/2005 speaks of information in defining two terms. Under Article 2 (2), in defining "rural land administration" is defined as a "process whereby ... information on farm plots and grazing land holders are gathered, analyzed and supplied to users'. Article 2 (16) provides that 'land information system means a system whereby rural land related information is gathered, analyzed and distributed users'. In both instances, however, the Law is not clear on which public body is duty bound to make the said information available. Nor is it clear whether the information is available on the initiative of the undesignated institution or upon request by users. The same ambiguous provision can also be found under Article 6 (5) of the same Proclamation where it requires the competent authority to register and keep information that describes the holder of rural land and other important information but it is not clear if the information 
This essentially answers the question who should make the information available. The fact that the laws require the institutions to make information available implies that failing to make information available amounts to violating the laws that require them to have the information readily available.

Some laws require institutions to establish information systems. Laws in this category include:

- the Definition of Powers and Duties of the Executive Organs Proclamation, ${ }^{65}$

- Biosafety Proclamation, ${ }^{66}$

- the Ethiopian Biodiversity Institute Reestablishment Regulation, ${ }^{67}$

- the Industrial Chemical Registration and Administration Proclamation, ${ }^{68}$

- the Ethiopian Water Resources Management Proclamation, ${ }^{69}$

is available to the public in any way. The Urban Land Lease Proclamation No. 721/2011 also has similar provisions. Article 10 requires the appropriate bodies to make information relating to urban land prepared for tender easily accessible to the public. Needless to say, the problem with provisions such as this is the fact that the institutions are less likely to make information available even where the institution is explicitly required by law, and one can imagine the result where the law uses ambiguous terms such as 'appropriate bodies'. On the other hand, under Article 32, the Ministry of Urban Development and Construction is, with the assistance of technology, to create a modernized and harmonized real property information system at the national level. It is not, again, clear whether the Ministry makes such information available at its own initiative or if the information is available upon request, if at all. By using the terms "chartered cities and urban administrations", the Urban Planning Proclamation also has ambiguous provisions as there is no explicitly designated institution. Article 35 of the Urban Planning Proclamation, for instance, states "[A]ny interested party shall be entitled to have information as to the development of a plot of land in the jurisdiction of an urban center." The provision, however, did not provide for the public body where interested persons may get the information from.

${ }^{65}$ Definition of Powers and Duties of the Executive Organs of the Federal Democratic Republic of Ethiopia Proclamation No. 1097/2018, 25 ${ }^{\text {th }}$ Year No. 8, Article 10(1)(c) and Article 32 (3)(1).

${ }^{66}$ Biosafety Proclamation No. 655/2009 15 th Year No. 63, Article 12(1) and (2). Under Article 2(15), a national biosafety clearing-house is defined as a "system of acquisition and management of, and access to, information established by the Authority based on Article 20 of the Protocol in order to facilitate the exchange of scientific, technical, environmental and legal information and experience with modified organisms".

${ }^{67}$ Ethiopian Biodiversity Institute Reestablishment Regulation No. 291/2013, $19^{\text {th }}$ Year No. 57, Article 6 (14).

${ }^{68}$ Industrial Chemical Registration and Administration Proclamation No. 1075/2018, 24 ${ }^{\text {th }}$ Year No. 40, Article 6.

${ }^{69}$ Ethiopian Water Resources Management Proclamation No. 197/2000, $6^{\text {th }}$ Year No. 25 , Article 10 (2), 10 (3) and 10 (4). 
The Legal Framework and Barriers to Access to Environmental Information in Ethiopia 155

- the Urban Landholding Registration Proclamation, ${ }^{70}$ and

- the Veterinary Drug and Feed Administration and Control Proclamation. ${ }^{71}$

Establishing and maintaining an information system is of course one of the best ways of making environmental information accessible to the public. This is because it is the public bodies that do the major part, which enables the public access to the information with minimal effort. As will be seen later on, one of the shortcomings of the provisions in these laws may be the lack of clarity regarding information in regional states. Although most of the laws are applicable in regional states, such ambiguity would leave much to be desired.

There are a number of laws that require institutions to undertake research, collect, analyze and disseminate information. They include:

- the Environmental Impact Assessment Proclamation, ${ }^{72}$

- Ethiopian Environment and Forest Research Institute Establishment Regulation, ${ }^{73}$

- Access to Genetic Resources and Community Knowledge, and Community Rights Proclamation ${ }^{74}$ and its Regulation, ${ }^{75}$

- River Basin Councils and Authorities Proclamation, ${ }^{76}$

${ }^{70}$ Urban Landholding Registration Proclamation No. 818/2014, $20^{\text {th }}$ Year No. 25 Articles 49 (3), 36 and 38.

${ }^{71}$ Veterinary Drug and Feed Administration and Control Proclamation No. 728/2011, $18^{\text {th }}$ Year No. 14, Article 20 (8). Veterinary Drug in the Proclamation means any substance or mixture of substances used in the diagnosis, treatment or prevention of animal (which includes domestic and wild animals, birds, aquatic animals, bees and silkworm) while "feed means material used as animal feed and produced or processed for commercial purpose".

72 Environmental Impact Assessment Proclamation No. 299/2002, $9^{\text {th }}$ Year No. 11, Article 15 (1).

73 Ethiopian Environment and Forest Research Institute Establishment Council of Ministers Regulation No. 327/2014, $21^{\text {st }}$ Year No. 5 Article 6 (7). For the definition of environment and forest research, see Article 2 (1), where reference is made to the generation and dissemination of technologies, information and knowledge.

74 Access to Genetic Resources and Community Knowledge, and Community Rights Proclamation No. 482/2006, $12^{\text {th }}$ Year No. 13, Article 27 (5).

75 Access to Genetic Resources and Community Knowledge, and Community Rights Council of Ministers Regulation No. 169/2009 $15^{\text {th }}$ Year No. 67, Article 7.

${ }^{76}$ River Basin Councils and Authorities Proclamation No. 534/2007, $13^{\text {th }}$ Year No. 40, Article 9 (6). The River Basin Councils and Authorities Proclamation No. 534/2007 envisages twelve basins (and their sub-basins) and states that river basins high councils and authorities will be established by regulations to be issued by the Council of Ministers. Examples are the Abay Basin, the Awash Basin and the Rift Valley Lakes Basin High Councils and Authorities, which have been established in accordance with 
- Ethiopian Wildlife Development and Conservation Authority

Establishment Proclamation, ${ }^{77}$

- Fisheries Development and Utilization Proclamation, ${ }^{78}$

- Ethiopian Agricultural Research Organization Proclamation, ${ }^{79}$

- Apiculture Resources Development and Protection Proclamation, ${ }^{80}$ and

- Energy Proclamation. ${ }^{81}$

As conducting research on the issues mentioned above is a daunting task, it may be argued that public bodies are better suited for the task. Public bodies are also better positioned to collect information from various sources, analyze and disseminate same to the public. As such, the provisions in the abovementioned laws are instrumental not only in promoting access to environmental information but also for informed decision making.

A few other laws require institutions to make periodic reports; such laws include the Definition of Powers and Duties of the Executive Organs Proclamation, ${ }^{82}$ and the Ethiopian Biodiversity Institute Reestablishment Regulation. ${ }^{83}$ Preparing and publishing periodic reports is a common trait in

Council of Ministers Regulations No. 151/2008, 156/2008 and 253/2011 respectively. See also Articles 6 (6) of the Abay Basin High Council and Authority Establishment Regulation No.151/2008 14 ${ }^{\text {th }}$ Year No. 30; Awash Basin High Council and Authority Establishment Council of Ministers Regulation No. 156/2008 14 $4^{\text {th }}$ Year No. 63; Rift Valley Lakes Basin High Council and Authority Establishment Council of Ministers Regulation No. 253/2011, $17^{\text {th }}$ Year No. 91.

77 Ethiopian Wildlife Development and Conservation Authority Establishment Proclamation No. 575/2008, $14^{\text {th }}$ Year No. 31, Article 6 (11). The provision employs the phrase 'provide to users' which implies that a passive access to environmental information is envisaged by the provision but a closer look at the Amharic version, which uses the term 'disseminate', it may be concluded that the provision has active access to environmental information whereby the Authority is expected to disseminate the information, as of duty, on its own initiative.

${ }^{78}$ Fisheries Development and Utilization Proclamation No. 315/2003, $9^{\text {th }}$ Year No. 32, Article 11.

${ }^{79}$ Ethiopian Agricultural Research Organization Proclamation No. 79/1997 $3^{\text {rd }}$ Year No. 42, Article 6 (8).

${ }^{80}$ Apiculture Resources Development and Protection Proclamation No. 660/2009 $16^{\text {th }}$ Year No. 6, Article 6.

${ }^{81}$ Energy Proclamation No. 810/2013, 20 th Year No. 12, Article 4 (9). The Ethiopian Energy Authority was established pursuant to Regulation No. 308/2014 in response to the requirements of the Energy Proclamation No. 810/2013.

82 Definition of Powers and Duties of the Executive Organs Proclamation supra note 65, Article 32 (3) (o).

${ }^{83}$ Ethiopian Biodiversity Institute Reestablishment Regulation, supra note 67, Article 6 (23). 
The Legal Framework and Barriers to Access to Environmental Information in Ethiopia 157

most environmental legislations, although not as common in the Ethiopian setting. The fact that the two most important organs in Ethiopia i.e. the Environment, Forest and Climate Change Commission (EFCCC) and the Biodiversity Institute are required to prepare and disseminate a periodic report on the state of the environment and biodiversity resource can indeed be taken as a good start for other laws to take inspiration from.

There is also another category of laws that require institutions to register and publicize information. Laws that fall under this category include Mining Operations Proclamation, ${ }^{84}$ Plant Breeder's Right Proclamation, ${ }^{85}$ Research and Conservation of Cultural Heritage Proclamation, ${ }^{86}$ and Urban Planning Proclamation. ${ }^{87}$ The information may relate to discovery, plans, application for licenses, grants or surrender of rights. Other laws should also make provisions for the register and publicizing of such important information to the public.

As can be seen from the above discussion on active access to environmental information in Ethiopia, the mechanism on how to make information available is not clear. The institutions would probably post certain information on their notice boards or even go to the extent of posting information using digital notice boards on the major streets of cities. ${ }^{88}$ The internet can also be an instrument given its importance as a robust information dissemination tool whose significance in fostering knowledge sharing cannot be understated. ${ }^{89}$ This of course presupposes the existence of a strong information technology personnel/department in each institution. ${ }^{90}$

${ }^{84}$ Mining Operations Proclamation No. 678/2010, $16^{\text {th }}$ Year No. 45 (as amended by Proclamation No. 816/2013) Article 14 (1) and 14 (2).

${ }^{85}$ Plant Breeder's Right Proclamation No. 1068/2017, $24^{\text {th }}$ Year No. 29, see Articles 17, 18 and 22.

${ }^{86}$ Research and Conservation of Cultural Heritage Proclamation No. 209/2000, $6^{\text {th }}$ Year No. 39, Article 38.

${ }^{87}$ Urban Planning Proclamation No. 574/2008, $14^{\text {th }}$ Year No. 29, Article 17.

88 Some Addis Ababa City Administration executive bodies were posting certain information on, for instance, notice boards in their premises and digital boards in some parts of Addis Ababa.

89 Thomas T. Ankersen (2003), 'Shared Knowledge, Shared Jurisprudence: Learning to Speak Environmental Law Creole (Criollo)', Tulane Environmental Law Journal, 16: 807-30 in Hayward, supra note, 13, at 204.

${ }^{90}$ The importance of ICT as a platform for providing information is manifested by the interest in international organizations such as the Joint Declaration on Freedom of Expression and the Internet, signed in 2011 by the United Nations, the Organization for Security and Co-operation in Europe, the Organization of American States and the 


\subsection{Passive access to environmental information}

Apart from the active access to information discussed above, passive access to environmental information is also envisaged under the legal framework on the environment in Ethiopia. This is either in the form of a registry or collecting and disseminating information upon request. For instance, under the Pesticide Proclamation, the Ministry of Agriculture is required to maintain a Pesticide Register which contains information on all registered pesticides in the country. ${ }^{91}$ The Ministry also maintains a separate central database or archive containing the inventory of all pesticides in order to track the movement and use of pesticides which may be available for a person who wants to have a copy upon payment of applicable fees. ${ }^{92}$

According to the Mining Operations Proclamation, the Ministry of Mining and Petroleum (or a state organ in charge of the mining sector) establishes and maintains a Registry of Licenses and Leases, which "contains details of all registered applications for licenses and all details of their granting or refusal and any other particulars as may be required". ${ }^{33}$ The Proclamation requires every "license, lease and instrument under which mining right is transferred, assigned, surrendered, suspended, revoked, encumbered, inherited or otherwise treated" to be registered in the Registry. ${ }^{94}$ The Registry, which contains all these relevant information, is open to the public for inspection. ${ }^{95}$

In accordance with its constitutive instrument, i.e. the Geological Survey of Ethiopia Establishment Proclamation, the Geological Survey of Ethiopia shall "collect and own information related to earth science studies, ${ }^{96}$ and may

African Commission on Human and Peoples' Rights. Access to Information, Participation and Justice in Environmental Matters in Latin America and the Caribbean: Situation, Outlook and Examples of Good Practice Second meeting of the focal points appointed by the Governments of the signatory countries of the Declaration on the application of Principle 10 of the Rio Declaration on Environment and Development in Latin America and the Caribbean Guadalajara, Mexico, 16 and 17 April 2013) 21.

${ }^{91}$ Pesticide Registration and Control Proclamation No. 674/2010 16 $6^{\text {th }}$ Year No. 52, Article 14 (1).

${ }^{92} I d$. Article 14(2) and (4).

${ }^{93}$ Mining Operations Proclamation, supra note 84, Article 15(1) and (2).

${ }^{94} \mathrm{Id}$. Article 15(3).

${ }^{95}$ Id. Article 15(4).

${ }^{96}$ Earth science is defined in the Law as a "science which studies the earth, the rocks of which it is composed, the changes that have undergone or are undergoing and other natural phenomena occurring within the earth, utilizing methods and techniques of geology, geophysics and geochemistry and any other method applicable for the study of the earth". See Geological Survey of Ethiopia Establishment Proclamation No. $194 / 20006^{\text {th }}$ Year No. 22, Article 2(1). 
The Legal Framework and Barriers to Access to Environmental Information in Ethiopia 159

make it available to users, with or without payment". ${ }^{97}$ Likewise, according to the Urban Planning Proclamation, the Ministry of Urban Development and Housing collects and organizes information relating to urban plans and make it available to those interested parties. ${ }^{98}$ Chartered cities and urban administrations also have the duty to make approved plans available to interested parties. ${ }^{99}$

Hence, when it comes to passive access to environmental information, public bodies are required to grant information whenever there is a request from interested persons. Some of the laws also require the payment of fees to have access to the environmental information concerned. But as indicated earlier, the laws that envisage passive access to environmental information are fewer in number than the laws that require active access to information.

\subsection{Exempted Information}

\subsubsection{Exempted information under the Constitution and the Access to Information Law}

The FDRE Constitution provides for the fundamental principles on the basis of which access to information may be limited. It provides that the rights of access to information "can only be limited through laws which are guided by the principle that freedom of expression and information cannot be limited on account of the content or effect of the point of view expressed". ${ }^{100}$ It further states that legal limitations may be employed to protect the well-being of the youth, and the honour and reputation of individuals. ${ }^{101}$

The Access to Information Law provides for the guiding principle with regard to the grounds in respect of which information might be exempted. It provides that access to information may only be limited by other laws if they are in line with the general exceptions found in Part Three of the Access to Information Law. It further states that "the mere fact that a record has been administratively classified as confidential does not, of itself, override the right of access unless it falls within the scope of an exception" provided in Part Three of the Proclamation. ${ }^{102}$

\footnotetext{
${ }^{97}$ Id. Article 6(6).

${ }^{98}$ Urban Planning Proclamation, supra note 87, Article 55(5).

${ }^{99}$ Id. Article 17(2).

${ }^{100}$ FDRE Constitution, Article 29(6).

${ }^{101}$ Ibid.

102 Access to Information Law, supra note 52, Article 15(2).
} 
Articles 16 to 27 of the Access to Information Law provide for the grounds in respect of which information may be exempted in accordance with the law. These are information relating to third party; commercial information of a third party; protection of confidential information of third party; third party notification and intervention; protection of safety of individuals and property; protection of proceedings of law enforcement and legal investigation; protection of records privileged from production in legal proceedings; defense, security and international relation of the country; cabinet documents; economic interests and financial welfare of the country and commercial activities of public bodies; operations of public bodies; and requests that are too broad, likely to divert resources or pertaining to information to be published in the future. Hence, except for these specifically stipulated grounds, a person may access information in the hands of public bodies.

\subsubsection{Exempted environmental information in Ethiopia}

Apart from providing for access to information as a right, whether active or passive, a number of environmental laws in Ethiopia have stipulated instances whereby certain environmental information will be exempted. For example, the Biosafety Law entitles an applicant to notify the EFCCC in writing, the information to be treated as confidential. ${ }^{103}$ Upon receiving the request for confidentiality, the EFCCC determines the information not to be confidential for biosafety and for other reasons and inform the same to the applicant, who then agrees or withdraws the application. ${ }^{104}$

The Access to Genetic Resources Regulation provides that "information communicated to the Ethiopian Biodiversity Institute in the course of access application or in the course of monitoring access will be made public and may be consulted by any interested person". ${ }^{105}$ However, the Regulation also provides that the Ethiopian Biodiversity Institute may, upon acceptable justification, grant confidential treatment of such information for a period of up to 10 years in respect of information which has not been divulged and could be used for disloyal commercial purposes for third parties. ${ }^{106}$

\footnotetext{
${ }^{103}$ Biosafety Proclamation, supra note 66, Article 13(1).

${ }^{104}$ Id. Article 13(2).

${ }^{105}$ Access to Genetic Resources Regulation, supra note 75, Article 7.

${ }^{106} I d$. Article 8(1). Pursuant to Article 8(3), it is up to the access applicant to request, in writing, (justifying the request for confidentiality) the information to be confidential. The Institute, should it elect to grant confidentiality, determines the information to be confidential and the term of confidentiality. See Access to Genetic Resources Regulation, supra note 75, Article 8(4). Thanks to the provisions of Article 8 (2), however, confidentiality may not be granted in respect of information on the
} 
The Legal Framework and Barriers to Access to Environmental Information in Ethiopia 161

Under Article 14 of the Pesticide Proclamation, the Ministry of Agriculture is required to maintain a Pesticide Register which contains a list and information on all registered pesticides. The Ministry also maintains a separate central database or archive which contains detailed information on issues pertaining to pesticides. Such information is accessible to the public provided that any person who wants to obtain a copy of such information pays the applicable fees. The only exception is that proprietary and confidential information are not accessible to the public. The Pesticide Advisory Board established by the Proclamation is in charge of formulating criteria and rules to be approved by the Ministry regarding which information should be considered proprietary and confidential. ${ }^{107}$ Interestingly, there is a penalty if a person knowingly releases information deemed proprietary or confidential. ${ }^{108}$

Under the Mining Operations Law, information, reports, documents or data submitted to the Licensing Authority or any other government agency will not be disclosed throughout the length of the license, unless the licensee gives his consent otherwise. ${ }^{109}$ The fact that information may be made available as the result of the consent of the licensee implies that such non-disclosure of the information results from one of the grounds of refusal envisaged under the Access to Information Law such as commercial information of the licensee or the protection of the safety of the licensee or his property.

\section{Remedies}

As can be seen from the discussion above, there are certain strictly established exceptions that are grounds for denial of information. The relevant authorities are expected to narrowly interpret these exceptions before denying information. ${ }^{110}$ Save for those exceptions, therefore, the authorities should

identification of the applicant, the genetic resource to be accessed, the locality where the genetic resource is found, the supplier of the genetic resource or the relevant institution accompanying and monitoring the access. This, hence, ensures that significant amount of information at least pertaining to the access application is outside the realm of confidentiality treatment. Moreover, under Article 9(1) of the Regulation, confidential information may be communicated to third parties upon court order, the expiry of the period of confidentiality, or mutual agreement of the parties.

${ }^{107}$ Pesticide Proclamation, supra note 91, Article 28 (1) (e).

${ }^{108}$ Id. Article 33 (3).

${ }^{109}$ Mining Operations Proclamation, supra note 84, Article 42 (1).

110 This differs according to the nature of the access required by law. Denial of access to information upon request is rampant in the case of passive access to information. In 
make the information available, the failure of which is against the Constitution and the Access to Information Law.

Denying information for no sufficient reason is against the Access to Information Law which states that no person may be required to give reason for the request of the information. Bringing the verdict of whether to grant or deny information into one's discretion rather than decide in accordance with the Law is a violation of the Constitution and the Access to Information Law. The Access to Information Law has put administrative and judicial remedies in place in cases where information is not made available without valid reasons. Complaint can be lodged before the head of public bodies, the Institution of the Ombudsman or an appeal can be filed before a court having jurisdiction. The provisions are also applicable to environmental information.

\subsection{Appeal to the head of public bodies}

According to the Access to Information Law, any person who wishes to obtain certain information from a public body may submit his request, clearly identifying the information he seeks, in writing or through electronic device, to the public relations officer of public bodies. ${ }^{111}$ Upon receiving the request, one of the alternatives available for the public relations officer is to reject the request, stating the reasons for doing so, which is also required to be made in writing. ${ }^{112}$ The public relations officer notifies the applicant of the response to his request in thirty working days from the receipt of the request. ${ }^{113}$

The first recourse for a person aggrieved by the decision of the public relation officer is to lodge his appeal to the concerned head of public body within 30 days from the day the decision is made. ${ }^{114}$ The head of the public body may accept the appeal even after the lapse of the 30 days if the appellant can prove sufficiently that he could not lodge his appeal due to force majeure. ${ }^{115}$ Upon receiving the appeal, the head of the public body has 10 days

the case of active access, it mostly involves authorities not discharging the responsibility bestowed upon them by law when they fail to collect, analyze and disseminate information on their own initiative.

${ }^{111}$ Access to Information Law, supra note 52, Article 14(1).

${ }^{112} I d$. Article 14(3). It should be noted that according to Article 14(5), failure to respond to a request within the 30 days period is deemed to be a refusal to grant the request, and accordingly be a ground for an appeal. This is of course notwithstanding the fact that the public relations officer may extend the 30 days period for a further 30 working days if one of the elements mentioned under Article 14 (8) are met.

113 Access to Information Law, supra note 52, Article 14 (3).

${ }^{114}$ Id. Article 31 (1).

${ }^{115}$ Id. Article 31 (2). 
The Legal Framework and Barriers to Access to Environmental Information in Ethiopia 163

to give his decision: i.e. whether to uphold or overturn the decision of the public relations officer. ${ }^{116}$

Public relations officers of each public body should submit annual report not later than May to the Ombudsman regarding the activities of the public body in implementing the access to information provisions of the Proclamation. ${ }^{117}$ Such reports would show the number of internal appeals made to the head of the public body and the number of granted and refused requests as a result of these internal appeals.

\subsection{Appeal to the Ethiopian Institution of Ombudsman}

The Access to Information Law reaffirms the constitutionally guaranteed right of access to information without the need to provide reasons for the request. ${ }^{118}$ A person who is aggrieved by the decision of the public relations officer and the head of the public body may lodge his appeal to the Institution of Ombudsman within 30 days of receiving that decision. ${ }^{119}$ The Law gives the Ombudsman the power to examine any record held by a public body in the process of reviewing any appeal. ${ }^{120}$ The Ombudsman may not, however, examine documents subject to a certificate issued under the Law and in doing so, ensures that any exempt information is not disclosed. ${ }^{121}$

Upon receiving the appeal, the Ombudsman has the following alternatives: it may request the public body to provide the requested information, or reject any appeal, or to take such other action as is appropriate to ensure that the

${ }^{116}$ Id. Article 31 (3).

${ }^{117} I d$. Article 36. The report, among other things, should contain the number of requests for access received; the number of requests for access granted in full, refused in full and partially refused; the number of appeals lodged to the Ombudsman and court appeals. Such reports should also be submitted by heads of public bodies to the Council of Ministers and House of Peoples' Representatives (in the case of Federal public bodies) or to national regional government councils and national regional councils (in the case of state public bodies).

118 Access to Information Law, supra note 52, Article 14 (1) and (2).

${ }^{119}$ Id. Article 31(4).

${ }^{120} I d$. Article 33(1).

${ }^{121} I d$. The certificate indicated in this provision relates to information in respect of national security, national defense or international relations mentioned under Article 23 of the Proclamation and would almost certainly cause serious harm to national security. The information envisaged in this provision, therefore, almost certainly have nothing to do with environmental information understood throughout the discussion in this piece. 
public body meets its obligations under the Proclamation. ${ }^{122}$ In any of the above instances, the Ombudsman has thirty days to decide on the appeal. ${ }^{123}$

One of the issues here is the thirty days given to the Ombudsman to decide. This is of course different from the time limit required for a person to lodge his appeal with the Ombudsman. As certain environmental issues are urgent in nature, one can imagine the impact of thirty days (forty days when we add the ten days that a person has to wait to lodge an appeal before the Ombudsman) unless the Ombudsman introduces an accelerated procedure to entertain and decide on environmental issues promptly. It may be up to the EFCCC and other stakeholders to come up with such an initiative to the attention of the Ombudsman.

\subsection{Appeal to court}

A person aggrieved by the decisions of the head of public bodies and the Ombudsman can take his appeal to courts. The Access to Information Law provides that a person aggrieved by the decision of the Ombudsman may lodge an appeal within thirty days to the federal First Instance Court and Regional High Court in respect of federal and regional public bodies respectively. ${ }^{124}$ Except for information in respect of which a certificate has been issued pursuant to Article 35 of the Access to Information Law, a court reviewing an appeal may examine any record of a public body and no such record may be withheld from it on any ground. ${ }^{125}$ In the course of deciding the matter, the court may not disclose any exempt information (so designated under the Law) and go to the extent of receiving evidence or hear argument in the absence of the applicant or his representative. ${ }^{126}$

The Law gives the Ombudsman the power to either order a public body to provide the requested information or reject an appeal. However, there is no such clear power of the court in the case of court appeals. It can also be argued that the courts (before which an appeal is brought) can order a public body to give the information or reject the appeal.

\footnotetext{
${ }^{122}$ Access to Information Law, supra note 52, Article 33 (3).

${ }^{123} I d$. Article $33(2)$.

${ }^{124}$ Id. Article 34 (1).

${ }^{125}$ Id. Article 34 (2).

${ }^{126} I d$. Article 34 (3).
} 
The Legal Framework and Barriers to Access to Environmental Information in Ethiopia 165

\section{Barriers to Access to Environmental Information in Ethiopia}

\subsection{The sector-based approach of environmental lawmaking in Ethiopia in the absence of framework environmental law}

Environmental lawmaking in Ethiopia is characterized as one whereby various public institutions propose and submit draft laws to the House of Peoples' Representatives, via the Council of Ministers, and become laws upon publication in the Negarit Gazeta. The EFCCC submits drafts on general matters of the environment. Other public institutions that may initiate draft laws (related to issues that may evoke environmental concerns) include the Ministry of Water on water resources, the Ministry of Agriculture and the Ministry of Mining on mineral resources. This means that different kinds of laws are enacted under the initiation of various institutions and are administered by the institution which initiated the law. These laws lack the level of consistency that one would expect for the protection of the environment.

The problem can easily be noticed when it comes to access to environmental information. While some laws completely ignore the idea of access to information, the laws with provisions on access are not designed in a consistent manner. This problem is compounded by the fact that there is no framework environmental law in Ethiopia that provides for certain fundamental principles, environmental rights etc. Such a framework legislation would have dealt with the issue of how legal provisions on access to environmental information should appear in environmental laws.

In the absence of such a framework law, the EFCCC should be more involved in the drafting of laws that regulate one or more issues of what we have come to understand as 'environment', as broadly defined in the Environmental Protection Organs Establishment Proclamation and the Environmental Pollution Control Proclamation. As it stands, however, the absence of a framework environmental law is one of the main barriers to access to environmental information in Ethiopia.

\subsection{Medium of dissemination}

Most of the environmental laws providing for active access to environmental information require the public bodies to collect, organize and disseminate information. The medium of dissemination of such information is, however, not clear. This creates uncertainty, although it should not be taken to be advocating for the laws to prescribe a certain form. The absence of a certain form to make environmental information available to the public, therefore, 
means that it is up to the public bodies to choose a medium for dissemination of information. The fact that the medium of dissemination is at the mercy of the public bodies can be taken as one of the barriers to access.

Some of the laws discussed above employ terms such as 'register' or 'database' to be established and maintained by the respective public bodies. It is again not clear whether such registers or database are digital or not. Public bodies are, hence, challenged to take the initiative to make such information available on, for example, the internet. Posting various environmental information on the internet is increasing in many countries. For example, as of 2013, twenty of the thirty-three countries in Latin America and the Caribbean "have made strides in generating electronic databases containing environmental information, referred to in some countries as environmental information systems". ${ }^{127}$ These kinds of initiatives and others designed to make information available to the public should be sought after in Ethiopia as well. This is required under a democratic order, and it enhances public participation in environmental protection endeavors.

\subsection{Gaps on the remedies}

The remedies available under the Access to Information Law seem to have envisaged passive access to information. This is inferred from the Access to Information Law which entitles persons aggrieved by the decision of the public relations officers of public bodies to lodge an appeal against a decision. However, most of the environmental laws are designed in such a way that the public bodies are to make information available on their own initiative i.e. active Access to Information. One may, therefore, argue that the remedies for unlawful denial of information are technically unavailable. The absence of remedies in the legal framework on the environment may also be taken as an important gap.

\subsection{Information delayed, information denied}

The timeframe envisaged by the Access to Information Law that one has to comply with before lodging an appeal is very problematic particularly for environmental issues. The Law provides for a few timeframes, starting from the response to the initial request for information to the appeal that lies before courts. First, the Law says public relations officers of public bodies 'shall as expeditiously as possible' either provide the information or reject the application, but the time cannot go beyond thirty working days. ${ }^{128} \mathrm{~A}$ person

\footnotetext{
${ }^{127}$ Access to Information, Participation and Justice in Environmental Matters in Latin America and the Caribbean supra note 90, at 21.

${ }^{128}$ Access to Information Law, supra note 52, Article 14 (3).
} 
The Legal Framework and Barriers to Access to Environmental Information in Ethiopia 167

aggrieved by the decision of the public relation officer's decision may lodge an appeal to the concerned head of the public body, who gives a decision within 10 days. ${ }^{129}$ A person still aggrieved by the decision of the head of the public body may lodge his appeal to the Institution of Ombudsman, which gives his decision within thirty days. ${ }^{130} \mathrm{~A}$ court that can receive the appeal against the decision of the Ombudsman (and that is the last resort in entertaining appeals) has thirty days to decide upon the appeal. ${ }^{131}$

It is understandable that the Access to Information Law is designed to deal with all kinds of information and hence, is not best suited to deal with matters of the environment. Environmental matters need to be dealt with urgency as the environment may be subject to devastating wrongdoings within a few days. The timeframe envisaged by the Access to Information Law may go as high as 108 days. This is detrimental to environmental protection endeavors; and it understandably overlooks environmental concerns that necessitate urgent remedies. This is because the instrumental effectiveness of access to environmental information is intrinsically dependent on its provision. Delay of environmental information for nearly four months can cause irreparable damage to the environment, and this illustrates the expression: information delayed, information denied.

The Access to Information Law has two exceptions with regard to the timeframe of the first response in respect of the initial application. The first exception is that a public relations officer may extend the 30 days period for a further period of not more than 30 working days, if one of the requirements are met. ${ }^{132}$ On the other hand, a public body has to respond to a request regarding a matter deemed urgent within a period of not more than ten working days. ${ }^{133}$ It is argued that most matters pertaining to the environment are urgent in nature and a request for environmental information needs to be handled in an expedited manner.

\subsection{Fees}

Most of the Laws examined in this article require some fees to be paid by the person applying for the information. Such fees to be paid by applicants may be one of the barriers to access to environmental information in Ethiopia. The Laws entitle the public bodies to set the amount of fee payable to access

\footnotetext{
${ }^{129}$ Id. Article 31 (1) and (3).

${ }^{130} I d$. Article 31 (4) and 33 (2).

${ }^{131} I d$. Article 34 (3).

${ }^{132}$ Id. Article 14 (8).

${ }^{133}$ Id. Article 14 (9).
} 
information. This implies that a person who does not afford to pay the fee payable upon request to access the information, cannot be granted access to the information he seeks.

The Access to Information Law states that the fees payable for access to information should not exceed the actual cost of searching, collecting and duplicating the record containing the information. ${ }^{134}$ Moreover, no fee should be charged for requests from those who cannot afford to pay. ${ }^{135}$ Given that environmental information is requested not for some personal gain but in line with the constitutional right to a clean environment and the duty of the public to protect the environment, it is argued here that most environmental information of public interest ${ }^{136}$ should be granted free of charge or only to the extent it covers certain administrative costs.

\subsection{Broad range of exempted information under the Access to Information Law}

The regime on environmental protection in Ethiopia has very limited exceptions on the basis of which environmental information may not be granted. The Access to Information Law provides that no law can provide for exceptions to the right of access to information, unless in line with the exceptions set forth under Part Three of the Access to Information Law. However, the Access to Information Law, which one resorts to claim his rights, has provided for grounds whereby public bodies may refuse to grant information. Articles 15 to 27 of the Access to Information Law provide public bodies a variety of alternatives to choose from to deny information. This severely limits the public's access to environmental information.

\subsection{Information in regional states}

One thing that is unclear, and which may be related to the environmental lawmaking in Ethiopia, is a question of where to find environmental information in regional states. Most of the environmental laws are applicable both at the federal and state levels. Public bodies at the federal level are explicitly required to make information available in accordance with the laws. Although some federal public bodies are required by law to collect information from regional states and disseminate same to the public, it remains unclear for the public because the public bodies (to collect information from and that have the duty to disseminate same to the public) are

\footnotetext{
${ }^{134}$ Id. Article 14 (12).

135 Ibid.

${ }^{136}$ Certain environmental information may be requested for personal interests. Examples include information relating to licenses of genetic resources, mining and others.
} 
The Legal Framework and Barriers to Access to Environmental Information in Ethiopia 169

not explicitly mentioned by laws. It may be argued that it should be the duty of the federal public bodies since the laws are enacted to be applicable in all regional states. It may, on the other hand, also be argued that regional state bodies share responsibility as custodians of information on laws, policies and activities in their spheres of influence. Both arguments, however, are just views and certainly do not answer the question of where to find environmental information in regional states.

As the trend in environmental lawmaking shows, some federal laws require certain institutions to be established at the state level. ${ }^{137}$ One may expect such institutions to make information available. Some other laws, on the other hand, require states to enact laws to implement the federal law in question. ${ }^{138}$ Such regional states laws may, therefore, point to the state public body who holds information. These are, however, mere assumptions and do not give concrete answer to the question at hand. While it is difficult to access information in the hands of public bodies who are required by law to make information available, it is doubly disconcerting to note that where to get information in the hands of regional state organs is not clear.

A tight way out with regard to information in the hands of regional state organs can be invoking the Environmental Protection Organs Establishment Proclamation which states that regional environmental agencies must "prepare reports on the respective state of the environment and sustainable development of their respective states and submit them to the [EFCCC]". ${ }^{139}$ It is then assumed that such regional organs are not just submitting the reports for the EFCCC to hold but to go on to analyze and disseminate the report to the public. Yet, the provision has two main shortcomings. First, the provision has regional environmental protection authorities in mind and no other public bodies which have mandates pertaining to the protection of the environment. Second, it only refers to reports and, therefore, other important environmental information is not included.

137 See, for example, the Environmental Protection Authority Proclamation No. 295/2002.

${ }^{138}$ An example in this category of federal laws is the Federal Rural Land Administration Proclamation No. 456/2005.

${ }^{139}$ Environmental Protection Organs Establishment Proclamation, supra note 39, Article $15(3)$. 


\subsection{Institutional barriers}

The FDRE Constitution embodies provisions on the right to healthy environment and guarantees the right of access to information. Moreover, the Access to Information Law implements the Constitutional guarantee of access to information, in addition to which many environmental legislations require public bodies to make environmental information available to the public. Going through the websites of some of the public bodies (that are required to make information available on their own initiative) shows the substantial gaps in this regard. This indicates that requesting information from public bodies is the only means of access to information. Unfortunately, denial of information seems to be the norm.

As can be seen from the discussion above, environmental information may be found in the hands of a variety of institutions. In the absence of a central body responsible for making environmental information available, one would expect the EFCCC to assume a leading role in that regard. Although it was established in mid-2013, as the Ministry of Environment, Forest and Climate Change, its website took years to be fully operational. This clearly defeats the requirement of EFCCC's constitutive instrument of "coordinating activities to ensure that the environmental objectives provided under the Constitution and the basic principles set out in the Environmental Policy are realized". ${ }^{140}$

Along with the constitutionally guaranteed right of access to information, certain policy objectives related to the environment deserve due attention. First, the government has the duty to ensure that all Ethiopians live in a clean and healthy environment. Second, people have the right to full consultation and to the expression of views in the planning and implementation of environmental policies and projects. Third, both the Government and citizens have the duty to protect the environment.

These environmental policy objectives can only be realized through making information available because information is instrumental in realizing one's right to live in a clean and healthy environment. Effective public participation may only be realized if the public is well informed of the laws and policies as well as of the planning and implementation of projects. Institutions such as the EFCCC should thus step up and make environmental information available and, by collaborating with other relevant institutions, act as a repository of information pertaining to the environment.

140 See Definition of Powers and Duties of the Executive Organs, supra note 65, Article 32 (3) (a). 
The Legal Framework and Barriers to Access to Environmental Information in Ethiopia 171

This should not in any way be taken to imply that the EFCCC is the sole institution with the duty in discussion. Each institution bestowed with making information available at its disposal pursuant to the relevant law obviously assumes the primary responsibility. While these institutions assume responsibility in accordance with the relevant specific law, the EFCCC assumes responsibility as a result of the Constitution, the Environmental Protection Policy as well as its constitutive instrument as the primary institution with the powers and duties of protecting the environment.

Moreover, public bodies are expected to collect environmental information from the private sector and, subject to the exceptions indicated in the laws, make the same available to the public. This is in line with the argument that access to environmental information must not be limited to information in the hands of public bodies only, as the private sector has become an important actor in various projects and activities which are obvious threats to the environment and natural resources such as water resources, soil, forests and wild animals. The information to be collected from the private sector and disseminated to the public may, inter alia, relate to impact assessment reports, technologies to be applied, and activities or processes which may have bearings on the environment.

\section{Conclusion}

Access to environmental information is a right on itself, and a precursor to all environmental rights. Moreover, it is an important component of democracy. As discussed above, this procedural environmental right injects life into substantive environmental rights thereby enabling the public to contribute in environmental protection as well as the conservation and management of natural resources.

The Constitution guarantees everyone's right to seek, receive and impart information and ideas of all kinds. The Access to Information Law, which implements the Constitution's access to information provision, reiterates the public's right to seek, obtain and communicate any information held by public bodies envisaged under the Constitution. As it stands, there is a commendable legal framework in Ethiopia guaranteeing the public's right of access to environmental information. Most environmental legislations in Ethiopia, which are steady growing in number during in the past two decades, incorporate provisions on access to environmental information.

However, there seem to be several barriers to the public's access to environmental information. Some of these barriers stem out of the environmental legislations themselves which fail to answer certain vital 
practical matters. In spite of the merits of the Access to Information Law, it may also be taken as a source of barriers against access to environmental information as it contains a broad range of exceptions. There are also certain institutional barriers to access whereby public bodies deny information without good cause.

The Constitution states that it is the duty of both the government and citizens to protect the environment. Needless to say, information is a prerequisite for any meaningful public engagement in environmental protection. Thus, there is the need to create public awareness on the constitutional duty to protect the environment and make demands, as of right, from the public authorities for environmental information. It also appears that there is a pressing need to create awareness among the public bodies that hold environmental information that making information available is the norm, the failure of which is contrary to the Constitution, the Access to Information Law and other environmental laws. Such awareness lays the basis for the relevant institutions to make information available to the public. There is also a need to revisit some of the major barriers to access and undertake appropriate reform with a view to making them consistent with the Constitution and other applicable laws. 